\title{
Feline immunodeficiency virus infection-a model for HIV and AIDS?
}

\author{
M. BENNETT and C. A. HART* \\ Departments of Veterinary Clinical Science and Animal Husbandry and * Medical Microbiology and Genitourinary \\ Medicine, University of Liverpool, PO Box 147, Liverpool L69 3BX
}

Feline immunodeficiency virus (FIV) is a lymphotropic lentivirus first isolated in California from domestic cats suffering from various clinical syndromes suggestive of underlying immunodeficiency. ${ }^{1}$ Since then, infection has been shown to be common in domestic cats throughout the world (surveys generally detect FIV antibody in 1-12\% of "healthy" cats and $10-20 \%$ of "sick" cats ${ }^{2,3}$ ) and closely related viruses have been detected in both captive and wild nondomestic felids. ${ }^{4,5}$ Although discovered only recently, FIV is also now one of the most studied feline viruses with a correspondingly large literature. The aim of this review is, therefore, to provide only a brief introduction to the field, concentrating particularly on those features of interest to comparative medicine.

FIV is a typical lentivirus in terms of its morphology and overall genome organisation ${ }^{1,6-8}$ but is more closely related to the other non-primate lentiviruses than to HIV. There are significant differences between the genomes of FIV and HIV, e.g., the presence in FIV of a long leader sequence $5^{\prime}$ to the major env glycoprotein gene, similar to that seen in Visna virus, and a pol gene-encoded dUTPase not found in primate lentiviruses. ${ }^{9}$ Spliced sequences encoding rev function have been identified in FIV ${ }^{10,11}$ but equivalents of nef and tat have not been identified. One aspect of FIV infection which might make it an attractive model for study of lentivirus evolution, both within individual hosts and between populations, is sequence variation in the env gene. The variation occurs mainly in nine clusters, ${ }^{8,12,13}$ two of which (V1 and V2) are in the leader sequence (which also encodes part of rev), and, therefore, do not form part of the mature envelope glycoproteins. Four clusters (V3-V6) occur in the region encoding the major surface glycoprotein (gp120) and three (V7-V9) in the transmembrane glycoprotein (gp41). Several of the variable regions have been shown to be epitopes for virus neutralising antibody. ${ }^{\text {14-16 }}$ Analysis of sequence variation across V3-V5 suggests that domestic cat FIV isolates can be divided into at least three distinct subtypes which

Received 25 Aug. 1994; accepted 1 Oct. 1994. cluster geographically. ${ }^{8}$ The amounts of variation within and between subtypes of FIV and HIV are strikingly similar, but far less variation among serial isolates from individual cats is seen than among HIV isolates from individual patients. Interestingly, the proportion of potentially silent nucleotide changes (as in contrast to changes that result in amino acid changes) in FIV env sequences is greater than that generally seen in HIV and may reflect greater coadaptation of FIV and the domestic cat. ${ }^{8}$

The natural epidemiology of FIV in domestic cats differs enormously from that of HIV in man. ${ }^{2,3}$ FIV is shed in the saliva and the main mechanism of transmission is thought to be through bites. Thus, most infected cats are adult ( $>5$ years old); males are generally twice as likely to be infected as females; freeroaming cats and non-pedigree cats are more frequently infected than cats kept at home and pedigree animals. As might be expected, prevalence is especially high among farm and feral cats $(24-38 \%$ antibody prevalence). ${ }^{2,3}$

Transmission from queens to kittens via milk has been recorded, ${ }^{17}$ but appears to play little role in the epidemiology of field infection. In addition, cats can be infected experimentally by most mucosal routes, including oral, vaginal and rectal ${ }^{17,18}$ (and D. A. Harbour, personal communication).

For most studies of pathogenesis, cats have been inoculated with cell-associated or cell-free FIV by subcutaneous, intramuscular, intravenous or intraperitoneal injection. The susceptibility of cats to infection and the severity of primary-stage clinical signs ${ }^{19}$ decrease with age, and most experiments have been done with cats inoculated as kittens. In such instances, virus can be re-isolated from blood after 1-3 weeks and antibody can be detected by ELISA after 3 weeks, although inoculation of low doses can significantly lengthen the time before viraemia and antibody detection. Cells susceptible to infection include $\mathrm{CD}^{+}$, $\mathrm{CD}^{+}$and B-lymphocytes, macrophages and astrocytes. $^{20-22}$ The CD4 antigen is not necessary for infectivity and recent studies suggest that the feline CD9 antigen may be the FIV receptor. ${ }^{23,24} \mathrm{~A}$ mild 
Table I. Secondary infections in FIV-related disease

Chronic respiratory disease (associated with felid herpesvirusand feline calicivirus infection)

Chronic stomatitis/gingivitis (associated with feline calicivirus and unidentified bacteria)

Persistent diarrhoea (associated with feline panleukopenia virus, various bacteria and coccidia)

Severe, rapid feline leukaemia virus infection

Severe cowpox virus infection

Staphylococcal pyoderma

Bacterial pneumonia

Pyothorax

Nocardiosis

Cryptococcosis

Candidiasis

Toxoplasmosis

Haemobartonellosis

Demodicosis

Notoedric mange

Table II. FIV infection as a model for HIV infection and AIDS

\begin{tabular}{ll}
\hline Advantages & Disadvantages \\
\hline FIV not infectious to man & $\begin{array}{c}\text { FIV is not HIV, and cats are } \\
\text { not human } \\
\text { Immunology of cat not as well } \\
\text { Readily obtainable, small, } \\
\text { easily handled host }\end{array}$ \\
$\begin{array}{c}\text { Large reservoir of naturally } \\
\text { infected animals }\end{array}$ & $\begin{array}{c}\text { Clinical histories not usually } \\
\text { readily available }\end{array}$ \\
$\begin{array}{c}\text { Natural lentivirus causing } \\
\text { disease in its natural host }\end{array}$ & $\begin{array}{c}\text { Difficult to produce, and long } \\
\text { wait for, end-stage disease }\end{array}$ \\
\hline
\end{tabular}

Areas in which FIV infection may be particularly good model:

Pathogenesis of early infection

Immunisation and immunotherapy

Chemotherapy in both cell culture and in whole animal

Virus variation/evolution within and between individuals and populations

lymphadenopathy with pyrexia and leucopenia usually develops 4-6 weeks after inoculation and lasts several months ${ }^{2,3,23}$ and this corresponds with a shift in virus distribution from predominantly $\mathrm{T}$ cells to macrophages and $\mathrm{B}$ cells. ${ }^{25,26}$ Acute infection is also marked by a rapid expansion in the $\mathrm{CD}^{+}$lymphocyte population, ${ }^{27}$ possibly similar to that more recently observed in man during acute HIV infection. ${ }^{28}$ Once recovered from the acute illness, cats remain healthy for at least several years - indeed, although in-vitro and in-vivo assays suggest progressive deterioration of immune function with time (e.g., decreased absolute T-cell numbers; decreased $\mathrm{CD}^{+}: \mathrm{CD}^{+}$ratios; decreased lymphoproliferation responses to mitogens and antigens; decreased MHCII expression; decreased titres of antibody, particularly IgM), it has proved difficult to reproduce the types of diseases seen in the field even in cats in which in-vitro assays suggest marked immunosuppression.

Several studies of naturally infected cats suggest that the period between infection and onset of terminal AIDS-like disease is usually at least 3-5 years. Clinical signs seen in cats with end-stage disease are largely associated with immunosuppression and secondary infection-chronic stomatitis, chronic respiratory disease, chronic weight loss and pyrexia are reported most frequently. ${ }^{2}$ Some specific infections which have been associated with FIV infection are listed in table I. Most of the organisms listed are normally mild pathogens or non-pathogenic in otherwise healthy cats, but are associated with more severe or chronic disease in FIV-infected cats. FIV infection has also been incriminated as the primary pathogen in lymphoma development, ${ }^{29}$ primary neurological disease, ${ }^{22}$ renal disease ${ }^{30}$ and various ophthalmic conditions $^{31}$ in cats.

Two areas in which FIV infection has been especially studied as a model for HIV and AIDS are antiviral therapy and immunisation. FIV inhibition in cell culture has been described for most nucleoside-analogue reverse transcriptase (RT) inhibitors tested, including $3^{\prime}$-azido-3'deoxythymidine (AZT), dideoxycytidine (ddC), 2',3'didehydro- $2^{\prime}-3^{\prime}$ dideoxythymidine (d4T), 2'3'-dideoxythymidine (ddT), 2'3'-dideoxyadenosine (ddA), $2^{\prime} 3^{\prime}$-dideoxyinosine (ddI), $2^{\prime}$-deoxy$3^{\prime}$-thiacytidine (3TC) and 9-(2-phosphonomethoxyethyl)adenine (PMEA). ${ }^{32-36}$ Among non-nucleoside RT inhibitors, phosphonoformate ${ }^{32,34}$ and several 4-amino-3,6-disulphonato-1,8-naphthalimide derivatives $^{36}$ inhibit FIV replication, but TIBO does not. ${ }^{34}$ FIV infection of cell cultures can also be inhibited by aurintricarboxylic acid and dextran sulphates, pradimicin $\mathrm{A}$ and heparin. ${ }^{34-36}$ There is some field evidence that the clinical signs associated with natural FIV infection may be improved by treatment with PMEA or AZT. ${ }^{33,37,38}$ However, in cats challenged experimentally, PMEA and AZT have been shown to delay but not to prevent FIV infection. ${ }^{33,39-41}$

Vaccination of cats with subunit vaccines has so far been unsuccessful, ${ }^{42-44}$ but some inactivated virus and cell-virus vaccines have provided protection against both homologous and moderately heterologous $(9 \%$ amino acid variation in env sequence) challenge viruses. ${ }^{4,44}$ The amount of envelope glycoprotein contained in the vaccine and the adjuvants used may be significant in determining the outcome of vaccination. ${ }^{43}$ Vaccination against other moderately or more heterologous viruses $(11 \%$ and $21 \%$ amino acid variation in $e n v$, respectively) was not successful. ${ }^{44}$ In a homologous system, at least, passive transfer of vaccine-induced serum and maternal antibody from vaccinated cats provided some protection even in the absence of anti-cellular antibodies, ${ }^{44,45}$ although maternal antibody does not generally afford protection to kittens. ${ }^{46}$ Little is as yet known about the doubtless important roles in protection played by anti-cellular antibody and $\mathrm{T}$-cell responses, particularly after more heterologous challenge.

Although some aspects of FIV infection in cats obviously differ greatly from those of HIV infection in man, FIV infection may provide a useful model for many other aspects of HIV infection (table II). Among 
the particular advantages of the FIV-cat model over many other models are its safety to laboratory personnel (FIV is not infectious to man), the opportunity to study lentivirus infection in a small, easily handled, outbred, natural host and the ready availability of natural cases for the study of, for example, virus

\section{References}

1. Pedersen NC, Ho EW, Brown ML, Yamamoto JK. Isolation of T-lymphotropic virus from domestic cats with an immunodeficiency-like syndrome. Science 1987; 235: 790-793.

2. Hopper CD, Sparkes AH, Harbour DA. Feline immunodeficiency virus. In: Chandler EA, Gaskell CJ, Gaskell RM (eds) Feline medicine and therapeutics, 2nd edn. Oxford, Blackwell Scientific Publications. 1994: 488.

3. Bennett M, Smylh NR. Feline immunodeficiency virus: a brief review. Br Vet J 1992; 148: 399-412.

4. Barr MC, Calle PP, Roelke ME, Scott FW. Feline immunodeficiency virus infection in non-domestic felids. $J$ Zool Wildl Med 1989; 20: 265-272.

5. Brown EW, Miththapala S, O'Brien SJ. Prevalence of exposure to feline immunodeficiency virus in exotic felid species. $J$ Zool Wildl Med 1993; 24: 357-364.

6. Elder JH, Phillips TR. Molecular properties of feline immunodeficiency virus (FIV). Infect Ag Dis 1993; 2: 361-374.

7. Miyazawa T, Tomonaga K, Kawaguchi Y, Mikami T. The genome of feline immunodeficiency virus. Arch Virol 1994; 134: 221-234.

8. Sodora DL, Shpaer EG, Kitchell BE, Dow SW, Hoover EA, Mullins JI. Identification of three feline immunodeficiency virus (FIV) env gene subtypes and comparison of the FIV and human immunodeficiency virus type 1 evolutionary patterns. $J$ Virol 1994; 68: 2230-2238.

9. Elder JH, Lerner DL, Hasselkus-Light CS et al. Distinct subsets of retroviruses encode dUTPase. $J$ Virol 1992; 66: 1791 1794.

10. Kiyomasu T, Miyazawa T, Furuya $T$ et al. Identification of feline immunodeficiency virus rev gene activity. $J$ Virol $1991 ; 65$ : 4539-4542.

11. Phillips TR, Lamont C, Konings DA et al. Identification of the Rev transactivation and Rev-responsive elements of feline immunodeficiency virus. $J$ Virol 1992; 66: 5464-5471.

12. Rigby MA, Holmes EC, Pistello M, Mackay A, Leigh Brown AJ, Neil JC. Evolution of structural proteins of feline immunodeficiency virus: molecular epidemiology and evidence of selection for change. J Gen Virol 1993; 74 : 425-436.

13. Pancino G, Fossati I, Chappey C et al. Structure and variations of feline immunodeficiency virus envelope glycoproteins. Virology 1993; 192: 659-662.

14. Pancino G, Chappey C, Saurin W, Sonigo P. B epitopes and selection pressures, in feline immunodeficiency virus envelope glycoproteins. $J$ Virol 1993; 67: 664-672.

15. Siebelink KHJ, Rimmelzwaan GF, Bosch ML, Meloen RH, Osterhaus ADME. A single amino acid substitution in hypervariable region 5 of the envelope protein of feline immunodeficiency virus allows escape from virus neutralization. J Virol 1993; 67: 2202-2208.

16. Lombardi S, Garzelli C, La Rosa C et al. Identification of a linear neutralization site within the 3 rd variable region of the feline immunodeficiency virus envelope. $J$ Virol 1993; 67: 4742-4749.

17. Sellon RK, Jordan HL, Kennedy-Stoskopf S, Tompkins MB, Tompkins WH. Feline immunodeficiency virus can be experimentally transmitted via milk during acute maternal infection. $J$ Virol 1994; 68: 3380-3385.

18. Bishop SA, Whiting CV, Gruffydd-Jones TJ, Harbour DA, Stokes CR. Aspects of mucosal immunopathogenesis with FIV. Abstract in Medical Research Council 7th Annual AIDS Workshop, Brighton, 1993.

19. George JW, Pedersen NC, Higgins J. The effect of age on the course of experimental feline immunodeficiency virus infection in cats. AIDS Res Hum Retroviruses 1993; 9: $897-905$. evolution. From the veterinary perspective, study of FIV as a model for HIV also creates a wealth of information about a clinically important feline pathogen, so these studies, especially of immunisation and chemotherapy, may provide as much benefit to the model species as to man.

20. Brown WC, Bissey L, Logan KS, Pedersen NC, Elder JH, Collisson EW. Feline immunodeficiency virus infects both $\mathrm{CD}^{+}$and $\mathrm{CD}^{+} \mathrm{T}$ lymphocytes. $J$ Virol 1991; 65 : 3359-3364.

21. Brunner D, Pedersen NC. Infection of peritoneal macrophages in vitro and in vivo with feline immunodeficiency virus. $J$ Virol 1989; 63: 5483-5488.

22. Dow SW, Poss ML, Hoover EA. Feline immunodeficiency virus: a neurotropic lentivirus. J Acquir Immune Defic Syndr 1990; 3: 658-668.

23. Norimine J, Miyazawa T, Kawaguchi Y et al. Feline CD4 molecules expressed on feline non-lymphoid cell-lines are not enough for productive infection of highly lymphotropic feline immunodeficiency virus isolates. Arch Virol 1993; 130: 171-178.

24. Willett BJ, Hosie MJ, Jarrett O, Neil JC. Identification of a putative cellular receptor for feline immunodeficiency virus as the feline homolog of CD9. Immunology 1994; 81: 228-233.

25. English RV, Johnson CM, Gebhart DH, Tompkins MB. In vivo lymphocyte tropism of feline immunodeficiency virus. $J$ Virol 1993; 67: 5175-5186.

26. Beebe AM, Dua N, Faith TG, Moore PF, Pedersen NC, Dandekar S. Primary stage of feline immunodeficiency virus infection: viral dissemination and cellular targets. $J$ Virol 1994; 68: 3080-3091.

27. Willett BJ, Hosie MJ, Callanan JJ, Neil JC, Jarrett O. Infection with feline immunodeficiency virus is followed by the rapid expansion of a $\mathrm{CD}^{+}$lymphocyte subset. Immunology $1993 ; 78: 1-6$.

28. Pantaleo G, Demarest JF, Soudeyns $\mathrm{H}$ et al. Major expansion of $\mathrm{CD} 8^{+} \mathrm{T}$ cells with a predominant $\mathrm{V} \beta$ usage during the primary immune response to HIV. Nature 1994; 370: 463-467.

29. Shelton GH, Grant CK, Cotter SM, Gardner MB, Hardy WD, DiaGiacomo RF. Feline immunodeficiency virus and feline leukemia virus infections and their relationships to lymphoid malignancies in cats: a retrospective study (1968-88). $J$ Acquir Immune Defic Syndr 1990; 3: 623-630.

30. Thomas JB, Robinson WF, Chadwick BJ, Robertson ID, Beetson SA. Association of renal-disease indicators with feline immunodeficiency virus infection. $J$ Am Anim Hosp Assoc 1993; 29: 320-326.

31. English RV, Davidson MG, Naisse MP, Jamieson VE, Lapin MR. Intraocular disease associated with feline immunodeficiency virus infection in cats. J Am Vet Med Assoc 1990; 196: 1116-1119.

32. North TW, North GLT, Pedersen NC. Feline immunodeficiency virus, a model for reverse transcriptase-targeted chemotherapy for acquired immune deficiency syndrome. Antimicrob Agents Chemother 1989; 33: 915-919.

33. Egberink $\mathbf{H}$, Borst $\mathbf{M}$, Niphuis $\mathbf{H}$ et al. Suppression of feline immunodeficiency virus infection in vivo by 9-(2-phosphonomethoxyethyl)adenine. Proc Natl Acad Sci USA 1990; 87: 3087-3091.

34. Cronn RC, Remington KM, Preston BD, North TW. Inhibition of reverse transcriptase from feline immunodeficiency virus by analogs of 2'deoxyadenosine-5'-triphosphate. Biochem Pharmacol 1992; 44: 1375-1381.

35. Smyth NR, McCracken CM, Gaskell RM et al. Susceptibility in cell culture of feline immunodeficiency virus to eighteen compounds. J Antimicrob Chemother 1994; 34: 589-594.

36. Tanabe-Tochikura A, Tochikura TS, Blakeslee JR, Olsen RG, Mathes LE. Anti-human immunodeficiency virus (HIV) agents are also potent and selective inhibitors of feline immunodeficiency virus (FIV)-induced cytopathic effect: development of a new method for screening of anti-FIV substances in vitro. Antiviral Res 1992; 19: 161-172. 
37. Hartmann K, Donath A, Beer B et al. Use of two virustatica (AZT, PMEA) in the treatment of FIV and FeLV seropositive cats with clinical symptoms. Vet Immunol Immunopathol 1992; 35: 167-175.

38. Smyth NR, Bennett M, Gaskell RM, Brown A, Gaskell CJ. Treatment for FIV? Vet Rec 1990; 126: 409-410.

39. Hayes KA, Lafrado LJ, Erickson JG, Marr JM, Mathes LE. Prophylactic ZDV therapy prevents early viraemia and lymphocyte decline but not primary infection in feline immunodeficiency virus inoculated cats. $J$ Acquir Immune Defic Syndr 1993; 6: 127-134.

40. Meers J, del Fierro GM, Cope RB, Park HS, Greene WK, Robinson, WF. Feline immunodeficiency virus infection: plasma but not peripheral blood mononuclear cell virus titer is influenced by zidovudine and cyclosporine. Arch Virol 1993; 132: 67-81.

41. Smyth NR, Bennett M, Gaskell RM, McCracken CM, Hart CA, Howe JL. Effect of 3'azido-2',3'-deoxythymidine on experimental feline immunodeficiency virus infection of domestic cats. Res Vet Sci 1994; 57: 220-224.

42. Hosie MJ, Osborne R, Reid G, Neil JC, Jarrett O. Enhancement after feline immunodeficiency virus vaccination. Vet Immunol Immunopathol 1992; 35: 191-197.

43. Hosie MJ. The development of a vaccine against feline immunodeficiency virus. $B r$ Vet $J$ 1994; 150: 25-39.

44. Johnson CM, Torres BA, Koyama H, Yamamoto JK. FIV as a model for AIDS vaccination. AIDS Res Hum Retroviruses 1994; 10: 225-228.

45. Hohdatsu T, Pu R, Torres BA, Trujillo S, Gardner MB, Yamamoto JK. Passive antibody protection of cats against feline immunodeficiency virus infection. $J$ Virol 1993; 67: 2344-2348.

46. Callanan JJ, Hosie MJ, Jarrett O. Transmission of feline immunodeficiency virus from mother to kitten. Vet Rec 1991; 128: 332-333. 